第54回真空夏季大学開催報告

吉 田肇 $* 1, * 2, * 3$

\title{
Report on the 54th Vacuum Summer School
}

Hajime YOSHIDA $* 1, * 2, * 3$

\begin{abstract}
${ }^{* 1}$ National Institute of Advanced Science and Industrial Technology, National Metrology Institute of Japan (AIST, NMIJ),
Umezono 1-1-1, Tsukuba-shi, Ibaraki 305-8563, Japan
\end{abstract}

(Received February 19, 2015, Accepted March 12, 2015)

\section{1. はじめに}

日本真空学会 教育委員会主催による, 第54回真空夏季大 学が, 松田七美男校長のもと9月 2 日から 5 日までの 4 日 間, 静岡県掛川市のヤマハリゾートつま恋1)で行われまし た. 参加人数は昨年より若干多い96名でした. 経験豊富な 9 名の講師によって, 気体分子運動論や表面科学といった物理 学から, 真空計測 ·真空ポンプ・真空部品などの真空工学, さらには成膜・プラズマといった真空応用まで, 幅広い内容 が講義されました. 講義の後には, 真空夏季大学の特色であ る, 演習が行われました. 演習では, 受講者は $15 \sim 16$ 名に 班分けされ, 与えられた問題を講師と一緒に, 関数電卓を駆 使して解くということを行いました。 また，今年は新たな試 みとして, ワールドカフェ方式の特別演習を行いました. ワールドカフェとは, 掉子や飲み物とともに，3〜4名で 一つのテーマについて自由に対話することです，そこでは， 対話を楽しむこと，相手の意見を否定しないで受け止めるこ と, ファシリテーター（議事進行する人）は置かないことな どの約束事があります。そして最終的には, 対話を通して, 何かに“気づき”，それを“行動”に繋げるきっかけとする ことを目的とします. 20 分間の対話を，メンバーを変えて 2 回行いました. 講師も受講者と同じ立場で特別演習に参加し ました。

以下に, アンケート結果を報告します。併せて, 真空夏季 大学の流れを感じて頂くために, ある演習講師の 4 日間を 時系列にまとめました。密度の濃い “真空漬け”の 4 日間
であることが，おわかり頂けるのではないかと思います。過 去の夏季大学開催報告と併せて, ご一読ください2-7).

\section{2. アンケート結果報告}

参加者の年齢構成, 所属機関業種, 職務内容, 現職年数 (アンケート結果) を図 1 に示します。これらの内訳は例年 ほぼ変化はありません. 年齢は23歳から 34 歳までが 9 割強 を占めています. 一方, 在職年数は, $0 \sim 1$ 年の方, $2 \sim 3$ 年 の方, $4 \sim 5$ 年の方, 6 年以上の方がほぼ同数ずつ抢られ, 幅広い職歴の方に受講されていることがわかります。業種は メーカーが最も多く, ユーザーも約 2 割抢られます. 職務 内容は設計, 研究開発, 製造, 装置開発で 8 割が占められ ています。例年通り若干ですが営業の方の参加もありまし た. 営業職の方が講義や演習をフォローするのは大変だと思 いますが, ユーザーとしては, 真空夏季大学で専門知識を身 に着けた営業の方が増えると大变嬉しいです。

真空技術者資格認定制度については, 本年度受験する方が 43 名, 次年度以降受験予定が 22 名抢られ, その内, 21 名が 「大いに役に立った」，14名が「少し役に立ちそう」と回答 されています．開会式で松田校長がおっしゃったように，

「夏季大学は, 真空技術者資格認定制度の予備校ではありま せんが, 夏季大学の講義・演習をこなしていれば苦もなく合 格するはず」ですので, 良い事前学習の機会にして頂ければ と思います。

講義の難易度に関するアンケート結果を Table 1 に示し ます。全体を見てみると「難しい」が 2 割強,「やや難しい」
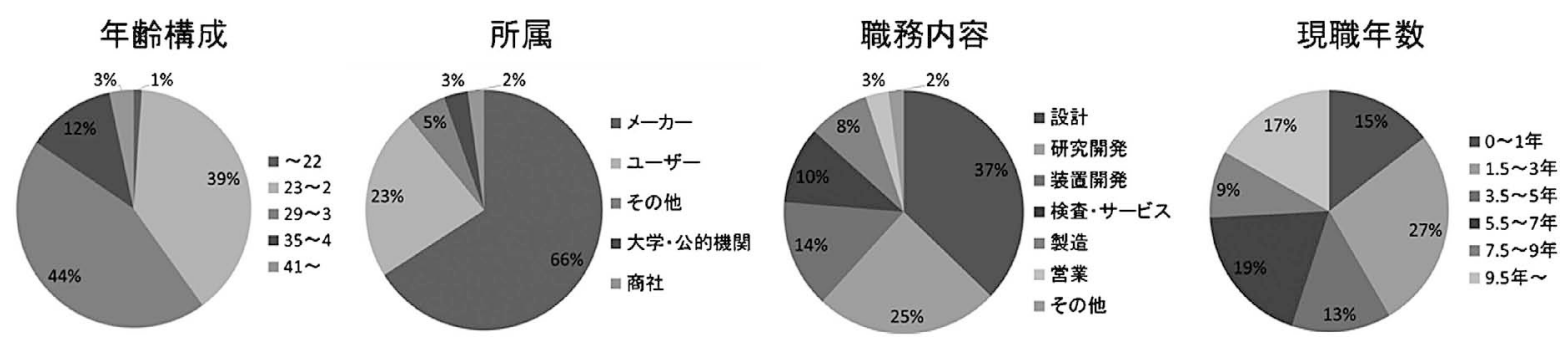

図 1 受講生のプロフィール.

*1 独産業技術総合研究所 計測標準研究部門 圧力真空標準研究室（干305-8563 茨城県つくば市梅園 1-1-1 つくば中央第 3)

*2 真空夏季大学演習講師

*3 現所属 : 国立研究開発法人 産業技術総合研究所 工学計測標準研究部門 圧力真空標準研究グループ 
Table 1 講義の難易度に関するアンケート結果。

(単位：\%)

\begin{tabular}{l|c|c|c|c|c}
\hline & 難 & やや難 & 普通 & やや易 & 易 \\
\hline 全体 & 24 & 53 & 20 & 0 & 2 \\
\hline 気体分子運動論 & 31 & 43 & 18 & 6 & 2 \\
\hline 真空と表面 & 23 & 47 & 22 & 6 & 2 \\
\hline 希薄気体の流れ & 31 & 46 & 18 & 4 & 1 \\
\hline 真空計測 & 14 & 43 & 39 & 2 & 1 \\
\hline 真空ポンプと排気系 & 9 & 43 & 39 & 8 & 1 \\
\hline 画像で見る真空工学 & 19 & 33 & 36 & 11 & 1 \\
\hline 真空材料とガス放出 & 11 & 43 & 36 & 7 & 3 \\
\hline 真空部品と可動機構 & 7 & 30 & 42 & 17 & 5 \\
\hline 成膜とプラズマの基礎 & 28 & 43 & 22 & 5 & 2 \\
\hline 演習 & 42 & 38 & 16 & 2 & 2 \\
\hline
\end{tabular}

が 5 割強,「易しい」と「やや易しい」が 0 と, 難しめの内 容となっています。また，約半数より講義内容が多すぎると いう意見が寄せられています。これは例年通りの傾向です。 実は, 主催者と致しましては, アンケート結果がこのように なることを承知の上でカリキュラムを組んでいます。なぜな ら，真空技術の理解のためには，非常に幅広い分野の知識が 必要とされますので，4 日間で全てをカバーすることは土台 無理なのです。しかし，4 日間で，多少無理矢理にでも，系 統的に真空科学・技術を学習したことは, 今後受講生が真空 に関する様々な課題や疑問に直面した時に，自らで考える拠 り所になるはずです，そう信じて，このようなカリキュラム を組んで抢りますので，ぞうぞご理解ください，

また，ワールドカフェ方式の特別演習について，感想を自 由記述してもらいました，結果は, 他社や異業種の方と交流 できてよかったなど，好意的な意見が大半でした，中には， 特別演習の時間が終わっても，引き続き，会話を続けている 方もいらっしゃいました，一方で，もっと多くの人と話した かったというご意見や，テーマ設定についてのご意見も頂き ました。

講師・スタッフ一同, これらアンケート結果を真摰に受け 止め, 真空夏季大学のブラッシュアップに努めて参ります. な抢, 達成度テストの平均点数は, 16 点満点中 11.8 点で, 昨 年並及でした。

\section{3. 真空夏季大学 ある演習講師の 4 日間}

\subsection{9 月 2 日（1日目）}

9:00 東京駅発，新幹線こだまに乗車.

$10: 40$ 掛川駅着.

$11: 15$ 駅前から無料送迎バスに乗車.

11: 30 ヤマハリゾートつま恋に到着.

$13: 00$ 「開校式」.

13：00「気体分子運動論入門 (90分間 1 コマ目)」聴講 (図 2).

$14: 45$ 「気体分子運動論入門 (90分間 2 コマ目)」聴講.

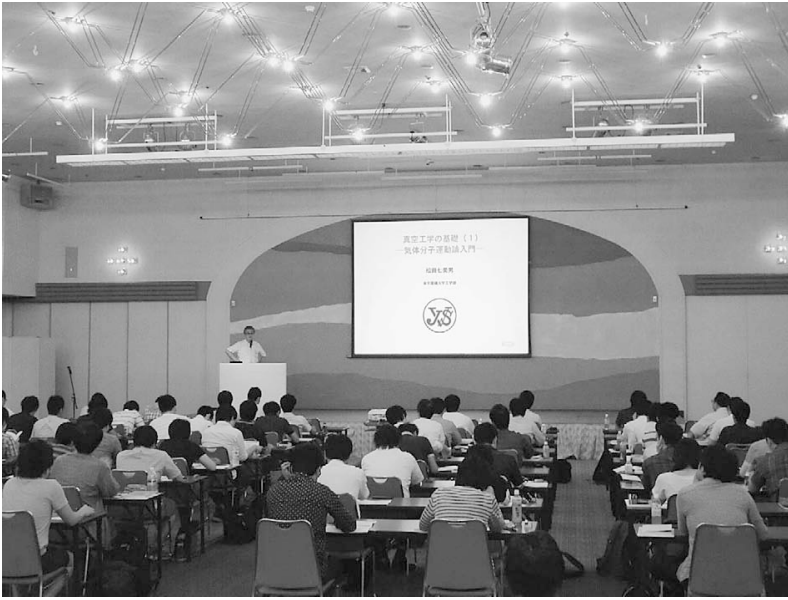

図 2 講義風景.

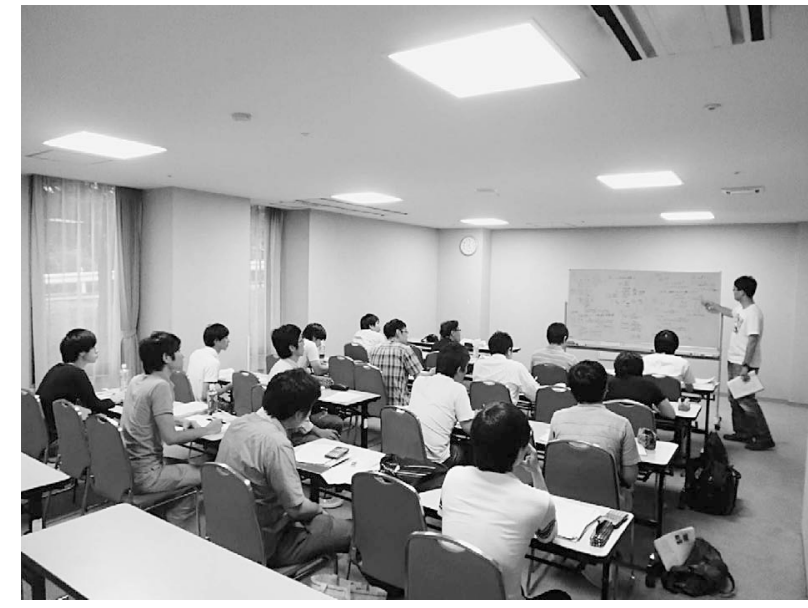

図 3 演習風景.

16：00 講義を途中退席し，演習講師による問題の解説方 法の打ち合わせ，その後，宿泊部屋に入る．4人 相部屋だが結構広い。「希薄気体の流れ（90分間）」 は残念ながら聴講できなかった。

18：00 夕食バイキング. 夕食後, 展示用の真空計一式を 並べる.

$19 ： 30$ 「演習（90分間）」を講義（図 3)。受講生には最低 1 回は前に出てホワイトボードで問題を解いてもら った．最後に，宿泊部屋毎に宿題を出す。

$22: 00$ 講師控室にて, 受講生からの質問を待つ.

$24: 00$ 就寝.

3.29 月 3 日 ( 2 日目)

$6: 30$ 起床, 大浴場で入浴.

$7: 30$ 朝食バイキング.

$8: 45$ 「真空と表面 (90分間 1 コマ目)」聴講.

$10: 15$ 「真空と表面（90分間 2 コマ目）」聴講.

12:00 昼食. カレー。

$13: 00$ 「真空計測（90分間 1コマ目）」聴講.

$14: 45$ 「真空計測 $(90$ 分間 2 コマ目)」聴講.

16：00 講義を途中退席し，演習講師による問題の解説方 法の打ち合わせ。「画像で反る真空工学 (90分間)」 
は残念ながら聴講できなかった。

18：00 夕食バイキング. 美味しいので, ついつい食べ過 ぎてしまう。

19 ：30「演習（90分間）」を講義. 受講生には最低 1 回は 前に出てホワイトボードで問題を解いてもらっ た。最後に宿泊部屋毎に宿題を出す.

$22 ： 00$ 講師控室にて, 受講生からの質問に答える.

$24: 00$ 就寝.

\subsection{9 月 4 日（ 3 日目）}

$6: 30$ 起床, 大浴場で入浴.

$7: 30$ 朝食バイキング.

8：45「真空ポンプと排気系（90分間 1コマ目)」聴講.

10 : 15 「真空ポンプと排気系 (90分間 2 コマ目)」聴講.

$12: 00$ 昼食. 打重に入ったお弁当.

$13: 00$ 「真空用材料とガス放出 (90分間)」聴講.

$14: 30$ 講義を途中退席し，演習講師による問題の解説方 法の打ち合わせに参加.「成膜とプラズマの基礎 (90分間)」は残念ながら聴講できなかった.

16：30 「演習（90分間）」を講義. 各部屋の代表者に問題 を解いてもらう。少々難しかったか。しかし，今 夜は宿題が無いので受講生も晴れ晴れ.

18：00 夕食バイキング。美味しいので，またまた食べ過 ぎてしまう。

19 ：30「特別演習」に参加. 色々な業種の人が，それぞ れ課題や悩みを抱えながら，真空技術に取組んで いることを実感した。

$22: 00$ 講師控室にて, 受講生からの質問に答える.

$24: 00$ 就寝.

3.49 月16日（4日目）

$6: 30$ 起床, 大浴場で入浴.

$7: 30$ 朝食バイキング.

$8 ： 45$ 「真空部品と可動機構 (90分間)」聴講. 途中退席
し，展示用の真空計一式を梱包し，返送.

$10: 30$ 「達成度テスト（90分間）」の試験官を務める.

11:45「終了式」. 皆様お疲れ様でした.

$12: 30$ 無料送迎バスに乗車して掛川駅へ。その後，帰 宅. 応用技術講座（「薄膜の基本技術」「「プロセス プラズマの基礎」,「真空システム」）の受講生は引 き続き，90分間 2 コマの講義を受講した.

\section{4.おわりに}

真空夏季大学の目標は, 「真空を扱う方々が真空技術の基 礎を理解し, 装置を正しく運用し, さらには新たな技術の展 開に応用できる能力を育むこと」です。マニュアル通りに真 空装置を運用するだけでなく，自らが工夫して，真空装置や 真空部品の改良や改造，さらには製作を行うためには，“最 低限知っておかなければならないこと”、確かに存在しま す．真空夏季大学では，これらを系統的に学習することがで き，さらに一歩上を行くヒントも，あちこちに散りばめられ ています．近年では，真空学会関西支部が実施している「役 に立つ真空技術入門講座」, 日本真空工業会が実施している 「真空ウォーキング8)」の講師・スタッフと，情報交換を密 にして抢り，協力して，より良いカリキュラム作りに励んで おります。講師一同頑張って準備いたしますので, 次回の真 空夏季大学にも多くの方にご受講頂けると幸いです.

\section{〔文献〕}

1) http://www.tsumagoi.net/ (Last accessed: 2015-03-13)

2) N. Sugiyama: Shinku, 50 (2007) 683.

3) A. Itakura and M. Tosa: J. Vac. Soc. Jpn., 52 (2009) 248.

4) A. Itakura: J. Vac. Soc. Jpn., 53 (2010) 53.

5) H. Akimichi: J. Vac. Soc. Jpn., 54 (2011) 134.

6) I. Arakawa: J. Vac. Soc. Jpn., 55 (2012) 204.

7) K. Shibata: J. Vac. Soc. Jpn., 56 (2013) 104.

8) http://jvia.gr.jp/kousyu_kouen/shinkuwarking/(Last accessed: 2015-03-13) 